\title{
Stability and Sensory Quality of Dried Papaya
}

\author{
Ronielli Cardoso Reis ${ }^{1 *}$, Eliseth de Souza Viana ${ }^{1}$, Siomara Costa Santana da Silva ${ }^{2}$, \\ Maria Eugênia de Oliveira Mamede ${ }^{3}$, Ídila Maria da Silva Araújo ${ }^{4}$
}

${ }^{1}$ National Cassava \& Fruits Research Center, Brazilian Agricultural Research Corporation (EMBRAPA), Cruz das Almas, Brazil

${ }^{2}$ Federal University of Bahia (UFBA), Salvador, Brazil

${ }^{3}$ State University of Feira de Santana (UEFS), Feira de Santana, Brazil

${ }^{4}$ Tropical Agroindustry Center, Brazilian Agricultural Research Corporation (EMBRAPA), Fortaleza, Brazil

Email: *ronielli.reis@embrapa.br

How to cite this paper: Reis, R.C., Viana, E.S., da Silva, S.C.S., Mamede, M.E.O. and Araújo, Í.M.S. (2018) Stability and Sensory Quality of Dried Papaya. Food and Nutrition Sciences, 9, 489-501.

https://doi.org/10.4236/fns.2018.95038

Received: March 29, 2018

Accepted: May 19, 2018

Published: May 22, 2018

Copyright $\odot 2018$ by authors and Scientific Research Publishing Inc. This work is licensed under the Creative Commons Attribution International License (CC BY 4.0).

http://creativecommons.org/licenses/by/4.0/

\begin{abstract}
Fruit dehydration is a way of supplying the population with healthy and nutritious foods. The shelf life of dried fruit can be defined by the evaluation of changes occurred in chemical characteristics during storage. This study aims to evaluate the sensory quality and the stability of papaya $\mathrm{cv}$. Tainung $\mathrm{n}^{\circ} 1$ dehydrated by convective drying. Fresh and dried papaya were evaluated for color, moisture, $\mathrm{pH}$, acidity, water activity, soluble solids, vitamin $\mathrm{C}$, carotenoids, total extractable polyphenols (TEP) and antioxidant activity (ABTS). The sensorial acceptance of the dried papaya was evaluated using a structured nine-point hedonic scale. For the stability study, the analysis of moisture, $\mathrm{pH}$, titratable acidity, water activity, total carotenoids and vitamin $\mathrm{C}$ were carried out every 30 days of storage until 120 days. During storage, the moisture content of dried papaya remained constant, but there were undesirable changes in color, increase of acidity and reduction of soluble solids. The degradation of total carotenoids and vitamin $\mathrm{C}$ followed the first order reaction, and the half-life time was 346 days for carotenoids, whereas for vitamin C it was only 29 days. In the sensory analysis, the dried papaya received grades between 5.0 and 6.0 for all evaluated attributes. Dried papaya is recommended to be consumed up to 30 days, since within this period a product with higher total carotenoids content, vitamin $\mathrm{C}$ and with satisfactory physicochemical and sensorial characteristics were obtained.
\end{abstract}

\section{Keywords}

Carica papaya, Carotenoids, Color, Dehydrated Fruit, Drying, Vitamin C

\section{Introduction}

The pulp of papaya (Carica papaya L.) has a pleasant aroma and taste, which are 
important qualities for sensorial acceptance for people of all ages. This fruit also presents interesting nutritional characteristics that include it in the select group of healthy foods. The chemical composition of papaya is in concordance with the cultivar, climate, cultural treatments and maturation stage. The Tainung $\mathrm{n}^{\circ}$ 1 variety presents, in $100 \mathrm{~g}$ of pulp, $45 \mathrm{kcal} ; 11.06 \%$ carbohydrate; $25 \mathrm{mg}$ of calcium; $17 \mathrm{mg}$ of magnesium; $222 \mathrm{mg}$ potassium; and $78.5 \mathrm{mg}$ of vitamin C [1].

Papaya is also an important source of carotenoids ( $\beta$-carotene, lycopene and $\beta$-cryptoxanthin) and phenolic (myricetin, fisetin, morin, quercetin, kaempferol and isorametina) [2] [3], which has an important antioxidant effect and contributes to the fruit sensory characteristics as color, taste and texture [4].

It is consumed preferentially fresh, but is a highly perishable fruit. It is estimated that losses occurring in the field, transportation and storage are 25\% [5]. Post-harvest losses also include the degradation of bioactive compounds that are essential for fruit quality [6]. Papaya industrialization is an alternative that makes it possible to minimize these losses and to use the fruits that are out of standard for commercialization. The application of appropriate technologies to preserve papaya nutritional properties is one of the ways to supply the population with healthy and nutritious processed foods.

Among the various conservation methods, drying is a relatively simple process in which water activity in food is reduced, minimizing or inhibiting the chemical and enzymatic reactions and microbial growth that are responsible for its deterioration [7]. Although different dehydration processes are used by the food industry, convective drying is the most common one, due to its easiness of processing and accessible technology [8].

During the fruit drying process, changes in appearance and color may occur and compromise the product acceptance. These changes occur through the action of the polyphenol oxidases enzymes that are present in the fruits, leading to the formation of melanins (dark pigments) from the oxidation of phenols to o-quinones [9]. This dimming can be minimized by immersion of the fruit in solutions with enzymatic inhibitors such as citric, phosphoric, malic or ascorbic acids [10].

Loss of nutrients, such as vitamin $\mathrm{C}$ and carotenoids, may occur during storage, thus reducing the nutritional value of dried fruit. Degradation of these nutrients depends on factors such as $\mathrm{pH}$, oxygen exposure, presence of light, metals, enzymes, temperature and the drying methods used [6] [10] [11].

In addition to the nutritional aspects, sensorial attributes must be evaluated in order to determine the quality of dried fruits. The aroma and flavor may be altered due to loss of volatiles during drying and storage of the dried fruits, leading to lower product acceptance [10].

The objective of this study was to evaluate the physicochemical characteristics, bioactive compounds, sensory acceptance and the stability of dried papaya obtained by convective drying. 


\section{Material and Methods}

\subsection{Sample Preparation}

Papaya (Carica papaya L.) fruits of Tainung $\mathrm{n}^{\circ} 1$ variety were purchased in local market and processed at maturity stage 4 (bark surface $50 \%$ to $75 \%$ yellow). The fruits were washed in water and immersed in solution with $100 \mathrm{mg} / \mathrm{L}$ of chlorine for 15 minutes. Fruits were peeled, the seeds removed and cut crosswise into 1.2 $\mathrm{cm}$ thick slices.

The slices were subdivided into pieces of $3.0 \times 3.0 \mathrm{~cm}$ and submitted to the following treatments: $\mathrm{T} 1-$ control treatment (without antioxidant treatment); T2-papaya immersion in solution containing $25 \mathrm{mg} / \mathrm{L}$ citric acid $+75 \mathrm{mg} / \mathrm{L}$ of ascorbic acid for 10 minutes, according to Reis et al. [12].

\subsection{Convective Drying}

The papaya slices ( $\mathrm{T} 1$ and $\mathrm{T} 2$ ) were dehydrated at $60^{\circ} \mathrm{C}$ in a dryer with fixed air velocity of $1.5 \mathrm{~m} / \mathrm{s}$ until reaching final humidity between $15 \%$ and $25 \%$ (w.b). The dried papayas were packed in polyethylene terephthalate/aluminum/polyethylene ( $\mathrm{PET} / \mathrm{Al} / \mathrm{PE})$ and stored for 120 days at room temperature $\left(28^{\circ} \mathrm{C} \pm 2^{\circ} \mathrm{C}\right)$.

\subsection{Physicochemical Analysis}

The fresh and dried papayas were evaluated for color, moisture, $\mathrm{pH}$, titratable acidity (TA), water activity $\left(\mathrm{a}_{\mathrm{w}}\right)$ and soluble solids (SS).

The color was determined using the colorimeter (Konica Minolta, model CR400, CIELAB system, illuminant D65). A sample of ten pieces of each treatment was analyzed. The coordinates $\mathrm{L}^{*}$ (lightness), $\mathrm{a}^{*}$ (green/red intensity) and $\mathrm{b}^{*}$ (blue/yellow intensity) and the color attributes $\mathrm{C}^{*}$ (color intensity/chroma) and $\mathrm{h}^{\star}$ (hue/color angle). The color variation $\left(\Delta \mathrm{E}^{\star}\right)$ was also calculated by the Equation (1) [13].

$$
\Delta E^{*}=\left[\left(L_{0}^{*}-L^{*}\right)^{2}+\left(a_{0}^{*}-a^{*}\right)^{2}+\left(b_{0}^{*}-b^{*}\right)^{2}\right]^{1 / 2}
$$

The analysis of moisture, $\mathrm{pH}$, soluble solids and titratable acidity were performed according to the Adolfo Lutz Institute [14]. The water activity was determined at $25^{\circ} \mathrm{C}$ by direct reading in water activity determinant (Aqualab Series 3/3TE).

\subsection{Bioactive Compounds and Antioxidant Activity}

The total carotenoid contents were determined according to Rodriguez-Amaya and Kimura [15]. The extraction was carried out with acetone, followed by the petroleum ether partition and the UV-visible spectrophotometer reading at 450 $\mathrm{nm}$. The results were expressed in $\mu \mathrm{g}$ of carotenoids per $\mathrm{g}$ of pulp.

The content of vitamin $\mathrm{C}$ was determined by the reaction of ascorbic acid with 2.6-dichlorophenol indophenol (DCFI), according to the procedure described by Oliveira [16], expressed in $\mathrm{mg}$ of ascorbic acid per $100 \mathrm{~g}$ of pulp. 
For the determination of TEP and antioxidant activity, papaya extracts were prepared as described by Larrauri et al. [17], with modifications. The extraction was done with $50 \%$ methanol for a period of 20 minutes in an ultrasonic bath, followed by centrifugation at $11,000 \mathrm{rpm}$ for 15 minutes. The residue was subjected to the second extraction in $70 \%$ acetone, following the same procedure. The extracts were mixed and transferred to the $50 \mathrm{~mL}$ volumetric flask, the volume was filled with distilled water. The TEP contents were determined using the Folin-Ciocalteau reagent (1:3) and the standard curve of gallic acid, according to the method described by Singleton et al. [18] and following the modifications proposed by Rufino et al. [19].

The total antioxidant activity was determined by capture of the radical ABTS according the methodology proposed by RE et al. [20], with modifications. The decrease in absorbance was measured after 6 minutes of reaction and the reading at $734 \mathrm{~nm}$. The results were expressed as $\mu \mathrm{M}$ trolox/g of fruit, from trolox standard curve.

\subsection{Stability of Dried Papaya}

The color, moisture, $\mathrm{pH}$, titratable acidity, water activity, total carotenoids and vitamin $\mathrm{C}$ were determinated at zero time and every 30 days of storage for a period of 120 days for the stability of the dried papaya. Degradation of the total carotenoids and vitamin $\mathrm{C}$ during storage followed the first-order reaction, and the data were evaluated using the following model:

$$
C=C_{0} \mathrm{e}^{-k t}
$$

where $C_{0}$ in $C$ that represent component concentrations at zero and $t$ time, respectively, and $k$ is the reaction rate constant $\left(\operatorname{time}^{-1}\right)$.

\subsection{Sensory Analysis}

The study was approved by the Research Ethics Committee of Maria Milza College, located in Governador Mangabeira, Bahia, Brazil (authorization $n^{\circ}$ 246/11). The sensory test was performed in individual cabins under white light by fifty not trained judges, with age between 18 and 60 years. The tests were carried out at 30-day storage. The acceptance test was made using a structured 9-points hedonic scale, in which 1 represents "dislike extremely" and 9 represents "like extremely". The attributes intensity of color, aroma, flavor and texture were evaluated using a nine-point intensity scale as described in Meilgaard et al. [21].

\subsection{Statistical Analysis}

All drying processes and all analysis were repeated three times. The one-way analysis of variance (ANOVA) was used to compare the two treatments of dried papaya ( $\mathrm{T} 1$ and $\mathrm{T} 2$ ) at $5 \%$ significance level, by $\mathrm{F}$ test. Results were expressed as mean \pm standard deviation.

The study of stability was performed in the completely randomized design in a split plot system. Two treatments (T1 and T2) constituted the plots and five sto- 
rage times $(0,30,60,90,120$ days) constituted the subplots. The data were analyzed by ANOVA at $5 \%$ significance level and regression analysis using Sisvar and $\mathrm{R}$ programs.

\section{Results and Discussion}

\subsection{Physicochemical Characteristics of Fresh and Dried Papaya}

The results of characterization of fresh and dried papaya (zero storage time) were shown in Table 1. The antioxidant treatment with citric acid and ascorbic acid (T2) used in papaya slices had no significant effect $(p>0.05)$ in physicochemical characteristics and in content of bioactive compounds when compared to the control treatment (Table 1). The dried papaya presented, on average, $23.42 \%$ moisture and water activity 0.57 . In general, these low values of moisture and water activity are sufficient to guarantee the microbiological stability of dehydrated products. According Sagar and Kumar [10], the pathogenic bacteria do not grow in products with $\mathrm{a}_{\mathrm{w}}$ below 0.85 , while fungi and yeasts are more tolerant and, to inhibit them, the product must have $\mathrm{a}_{\mathrm{w}}$ lower than 0.62 . Therefore, the dried papaya obtained in this study can be considered as a microbiologically stable product.

Table 1. Physicochemical characteristics of fresh and dried papaya (zero storage time)-values on a wet basis.

\begin{tabular}{|c|c|c|c|c|}
\hline \multirow{2}{*}{ Physicochemical Characteristics } & \multirow{2}{*}{$\begin{array}{l}\text { Fresh } \\
\text { Papaya }\end{array}$} & \multicolumn{3}{|c|}{ Dried Papaya } \\
\hline & & $\mathrm{T} 1^{(1)}$ & $\mathrm{T} 2^{(2)}$ & Average $^{(3)}$ \\
\hline Humidity (\%) & $88.82 \pm 0.85$ & $20.06 \pm 5.89^{\mathrm{a}}$ & $26.78 \pm 4.71^{\mathrm{a}}$ & $23.42 \pm 4.75$ \\
\hline Titratable acidity, TA (\% citric acid) & $0.10 \pm 0.01$ & $0.94 \pm 0.04^{\mathrm{a}}$ & $0.83 \pm 0.09^{\mathrm{a}}$ & $0.89 \pm 0.08$ \\
\hline $\mathrm{pH}$ & $5.11 \pm 0.13$ & $5.15 \pm 0.17^{\mathrm{a}}$ & $4.98 \pm 0.22^{\mathrm{a}}$ & $5.06 \pm 0.12$ \\
\hline Soluble solids, SS ( ${ }^{\circ}$ Brix) & $10.78 \pm 0.55$ & $156.43 \pm 26.01^{\mathrm{a}}$ & $123.92 \pm 21.94^{\mathrm{a}}$ & $140.18 \pm 22.98$ \\
\hline SS/TA & $106.69 \pm 14.02$ & $166.47 \pm 26.76^{\mathrm{a}}$ & $150.44 \pm 33.12^{\mathrm{a}}$ & $158.46 \pm 11.34$ \\
\hline$a_{w}$ & $0.94 \pm 0.02$ & $0.55 \pm 0.03^{\mathrm{a}}$ & $0.58 \pm 0.09^{\mathrm{a}}$ & $0.57 \pm 0.02$ \\
\hline Total carotenoids $(\mu \mathrm{g} / \mathrm{g})$ & $36.38 \pm 1.61$ & $219.99 \pm 7.25^{\mathrm{a}}$ & $218.92 \pm 20.95^{a}$ & $219.46 \pm 0.76$ \\
\hline Vitamin C (mg/100g) & $53.84 \pm 4.88$ & $375.54 \pm 18.27^{\mathrm{a}}$ & $269.96 \pm 66.92^{\mathrm{a}} 3$ & $322.61 \pm 74.85$ \\
\hline TEP (mg GAE/100g) & $47.04 \pm 1.17$ & $274.70 \pm 107.80^{\mathrm{a}}$ & $263.50 \pm 91.13^{\mathrm{a}}$ & $269.09 \pm 7.92$ \\
\hline ABTS $(\mu \mathrm{M}$ trolox/g) & $4.35 \pm 0.34$ & $8.27 \pm 2.69^{\mathrm{a}}$ & $7.44 \pm 2.58^{\mathrm{a}}$ & $7.86 \pm 0.59$ \\
\hline $\mathrm{L}^{*}$ & $53.68 \pm 2.38$ & $55.08 \pm 6.00^{\mathrm{a}}$ & $51.35 \pm 4.43^{\mathrm{a}}$ & $53.22 \pm 2.64$ \\
\hline$a^{*}$ & $26.85 \pm 0.48$ & $37.35 \pm 1.46^{\mathrm{a}}$ & $35.52 \pm 3.71^{\mathrm{a}}$ & $36.44 \pm 1.30$ \\
\hline$b^{*}$ & $41.88 \pm 2.36$ & $49.98 \pm 6.66^{\mathrm{a}}$ & $47.79 \pm 4.29^{\mathrm{a}}$ & $48.89 \pm 1.54$ \\
\hline $\mathrm{C}^{*}$ & $49.92 \pm 1.86$ & $62.68 \pm 5.34^{\mathrm{a}}$ & $59.79 \pm 5.22^{\mathrm{a}}$ & $61.24 \pm 2.04$ \\
\hline$h^{*}$ & $57.29 \pm 1.79$ & $52.97 \pm 3.82^{\mathrm{a}}$ & $52.99 \pm 1.02^{\mathrm{a}}$ & $52.98 \pm 3.82$ \\
\hline$\Delta \mathrm{E}^{*}$ & - & $11.69 \pm 0.74^{\mathrm{a}}$ & $12.51 \pm 2.60^{\mathrm{a}}$ & $12.10 \pm 0.60$ \\
\hline
\end{tabular}

Means followed by the same letter in the same row are not significantly different $(p>0.05)$ by $\mathrm{F}$ test. ${ }^{(1)}$ Control Treatment; ${ }^{(2)}$ Immersion in aqueous solution containing $25 \mathrm{mg} / \mathrm{L}$ citric acid $+75 \mathrm{mg} / \mathrm{L}$ ascorbic acid for 10 minutes. ${ }^{(3)}$ Average values of treatments T1 and T2; $\mathrm{a}_{\mathrm{w}}$ : water activity; TEP: total extractable polyphenols; $\mathrm{ABTS}=$ antioxidant activity by the ABTS method; $\Delta \mathrm{E} *=$ total variation of color dried papaya compared to fresh papaya. 
After drying process, the solids and organic acids of papaya were concentrated. The SS/TA increased $48.52 \%$, which may positively influence in the acceptance of the dried papaya by consumers, since products with higher SS/TA have more pronounced sweetness. There were also increased levels of bioactive compounds in dried papaya, where values were approximately six times higher than those presented in fresh one. The increase in concentration of these compounds, promoted the increase of its antioxidant activity, which passed from 4.35 for fresh to $7.86 \mu \mathrm{M}$ trolox/g for dried papaya ( $\mathrm{T} 1$ and $\mathrm{T} 2$ average) (Table $1)$.

The use of the citric acid and ascorbic acid combination did not have a significant effect $(p>0.05)$ on coloration of dried papaya (Table 1$)$. By comparing the chromatic attributes of fresh and the dried papaya (T1 and T2 average), it was found that the lightness of papaya $\left(\mathrm{L}^{*}\right)$ did not change during the drying process, indicating that there was no browning of the product. However, the dried papaya showed a more intense and more reddish color than the fresh papaya, which can be seen by the higher values for $\mathrm{a}^{*}$ and $\mathrm{C}^{*}$ and lower values for $\mathrm{h}^{*}$. These results may be associated with the concentration of papaya carotenoids after drying, especially lycopene, which is the main carotenoid on fresh papaya and responsible for the red color of the fruit [22]. Mishra et al. [5] also observed an increase in the values of $\mathrm{a}^{*}$ coordinate in dehydrated papaya by using a combination of osmotic dehydration and infrared drying. However, different from that observed in this study, $\mathrm{L}^{*}$ decreased and the product presented a reddish brown coloration. Different results from this study was also observed by Canizares and Mauro [23], in which papayas dehydrated by convective drying at $60^{\circ} \mathrm{C}$ and $70^{\circ} \mathrm{C}$ showed more yellowish color and less intense than the fresh papaya.

The total color variation, $\Delta \mathrm{E}^{*}$, was 12.10 (Table 1 ), a value close to that reported by Chong et al. [9], which was 10.36, in papaya dried by hot-cold air technology. Despite close values, in the study conducted by Chong et al. [9], papaya color changed from deep red to yellow-brown, an opposite result to the present study. According to these authors, the use of high drying temperatures, above $70^{\circ} \mathrm{C}$, in spite of promoting the inactivation of the PPO enzyme, favor the oxidation of papain enzyme, releasing free amino acids that react with the reducing sugars of the papaya, triggering the Maillard reaction. Therefore, the drying temperature used in this study $\left(60^{\circ} \mathrm{C}\right)$ was satisfactory, allowing color preservation and obtaining a dried product with high concentration of bioactive compounds.

\subsection{Degradation of the Bioactive Compounds of Papaya after Drying}

When comparing the contents of the bioactive compounds on dry basis (Table 2 ), some of these compounds were lost after drying. There was loss of $17.69 \%$ for TEP and dried papaya showed an average of $347.36 \mathrm{mg} \mathrm{GAE} / 100 \mathrm{~g}$. Chong et al. [9], evaluate the effect of different papaya dehydration methods and found losses 
Table 2. Degradation of the bioactive compounds of papaya after drying process (zero storage time)—values on a dry basis.

\begin{tabular}{|c|c|c|c|c|c|c|}
\hline \multirow{2}{*}{ Bioactive compounds } & \multirow{2}{*}{ Fresh Papaya } & \multicolumn{3}{|c|}{ Dried Papaya } & \multirow{2}{*}{$\%$ Degradation $^{(4)}$} & \multirow{2}{*}{$\%$ Retention $^{(5)}$} \\
\hline & & $\mathrm{T} 1^{(1)}$ & $\mathrm{T} 2^{(2)}$ & Average $^{(3)}$ & & \\
\hline TEP (mg GAE/100g) & $422.01 \pm 26.72$ & $338.31 \pm 111.07 \mathrm{a}$ & $356.40 \pm 106.18 \mathrm{a}$ & $347.36 \pm 12.79$ & 17.69 & 82.31 \\
\hline Vitamin C (mg/100g) & $481.23 \pm 8.37$ & $471.53 \pm 42.33 \mathrm{a}$ & $365.63 \pm 72.45 \mathrm{a}$ & $418.58 \pm 74.88$ & 13.02 & 86.98 \\
\hline Carotenoids $(\mu \mathrm{g} / \mathrm{g})$ & $329.53 \pm 4.00$ & $264.79 \pm 17.25 a$ & $305.23 \pm 5.92 \mathrm{a}$ & $285.00 \pm 28.59$ & 13.51 & 86.95 \\
\hline ABTS $(\mu \mathrm{M}$ trolox/g) & $39.12 \pm 5.22$ & $10.42 \pm 3.60 \mathrm{a}$ & $10.32 \pm 4.18 \mathrm{a}$ & $10.37 \pm 0.07$ & - & - \\
\hline
\end{tabular}

Means followed by the same letter in the same row are not significantly different $(p>0.05)$ by $\mathrm{F}$ test. ${ }^{(1)}$ Control Treatment; ${ }^{(2)}$ Immersion in aqueous solution containing $25 \mathrm{mg} / \mathrm{L}$ citric acid $+75 \mathrm{mg} / \mathrm{L}$ ascorbic acid for 10 minutes; ${ }^{(3)}$ Average values of treatments $\mathrm{T} 1$ and $\mathrm{T} 2 ;{ }^{(4)} \mathrm{Calculated}$ for average value of treatment $\mathrm{T} 1$ and $\mathrm{T} 2$ in relation of fresh papaya; ${ }^{(5)}$ Calculated by difference between 100 and the $\%$ of degradation.

from $7 \%$ to $69 \%$ for phenolic content, and the dried product had contents from 84.78 to $250 \mathrm{mg} \mathrm{GAE} / 100 \mathrm{~g}$, lower values than the results of this study.

Degradation of vitamin C during the drying process was only $13.02 \%$ (Table 2), representing $86.98 \%$ of retention of vitamin $\mathrm{C}$ in the dried product ( $\mathrm{T} 1$ and T2 average). These values were similar to those reported by Garcia et al. [24], which found a retention of $83.03 \%$ and $87.30 \%$, in dehydrated papaya at $60^{\circ} \mathrm{C}$ and $70^{\circ} \mathrm{C}$, respectively. Hawlader et al. [25] investigated the dehydration of guava and papaya using the same drying conditions of the present study and verified that $75 \%$ of vitamin $\mathrm{C}$ was retained in papaya and only $25 \%$ in guava. This result suggests that vitamin $\mathrm{C}$ degradation is dependent on the food matrix and that papaya may present a natural barrier to oxidation during drying [24]. Another factor that interferes on the degradation of bioactive compounds is the drying parameters used. Kurozawa et al. [26] observed that increasing air velocity promotes a greater retention of vitamin $\mathrm{C}$ in dried papaya at $60^{\circ} \mathrm{C}$, a fact that is associated with the shorter time papaya is exposed to high temperatures. This may explain the high vitamin $\mathrm{C}$ retention of dried papaya in this study.

For carotenoids, the drying process employed promoted the $13.51 \%$ degradation. Factors such as high temperature, presence of light, oxygen, acids and metals can promote the degradation of these pigments during the drying process. However, Udomkun et al. [27], tested several drying temperature combinations $\left(50^{\circ} \mathrm{C}, 60^{\circ} \mathrm{C}, 70^{\circ} \mathrm{C}\right.$ and $\left.80^{\circ} \mathrm{C}\right)$, air velocity $(0.2,0.5$ and $0.7 \mathrm{~m} / \mathrm{s})$ and air specific humidity (10 and $25 \mathrm{~g}$ water/kg of dry air), in papaya dehydration process, and found losses of $5.7 \%$ to $75 \%$ of $\beta$-carotene content, and from $34.66 \%$ to $76.41 \%$ of lycopene content, but did not find a direct relationship between these variables and the degradation of the evaluated carotenoids. The low degradation of carotenoids during the papaya drying may be related to the moisture reduction of the product. According to Goula et al. [28], the kinetics of lycopene degradation depends on product moisture, and when the moisture content is high (55\% - 95\%), chemical reactions occur faster than in low moisture content (below $55 \%)$. This is due to the greater solubilization and mobility of the catalytic substances in the reaction. Di Scala and Crapiste [29] verified the same behavior during the drying of red peppers. 


\subsection{Stability of Dried Papaya}

\subsubsection{Physicochemical Changes during Storage}

The stability of the dried papaya during storage can be observed in Figures 1-3. No significant difference $(p>0.05)$ was observed between the control treatments (T1) and with addition of $25 \mathrm{mg} / \mathrm{L}$ citric acid $+75 \mathrm{mg} / \mathrm{L}$ ascorbic acid (T2) during storage. However, the physicochemical caracteristics of dried papaya changed significantly $(p<0.05)$ during the storage (Figure 1$)$. The acidity increased and the soluble solids content reduced, leading to SS/TA reduction. The SS/TA decreased from 158.46 to 53.30, thus compromising the quality of the dried papaya (Figures 1(a)-(c)). Probably this reduction was due to reaction between reducing sugars present in papaya and free amino groups resulting in the formation of intermediate compounds such as $\mathrm{CO}_{2}$ and acids (Maillard reaction).

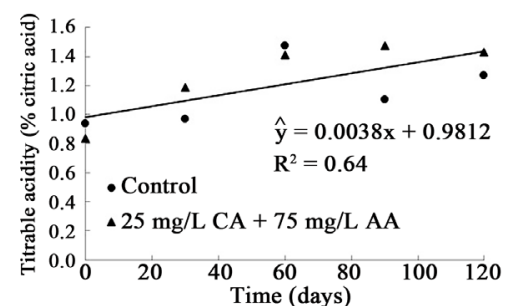

(a)

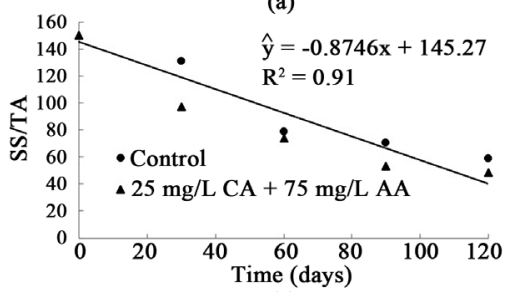

(c)

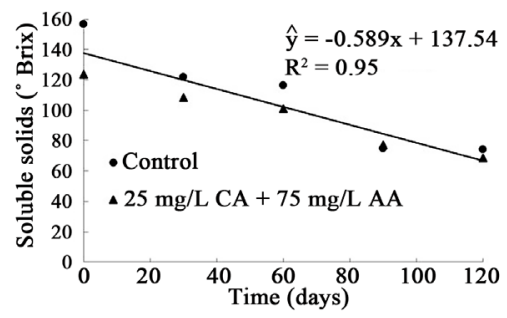

(b)

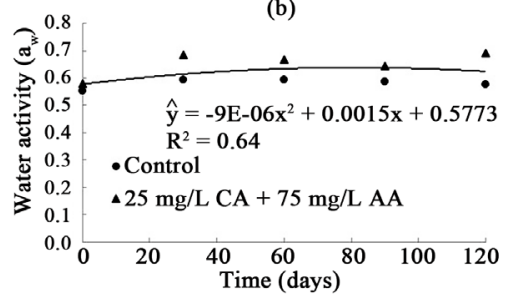

(d)

Figure 1. Physicochemical characteristics changes of the dried papaya during storage. Lines represent the linear model adjusted. CA: citric acid; AA: ascorbic acid.
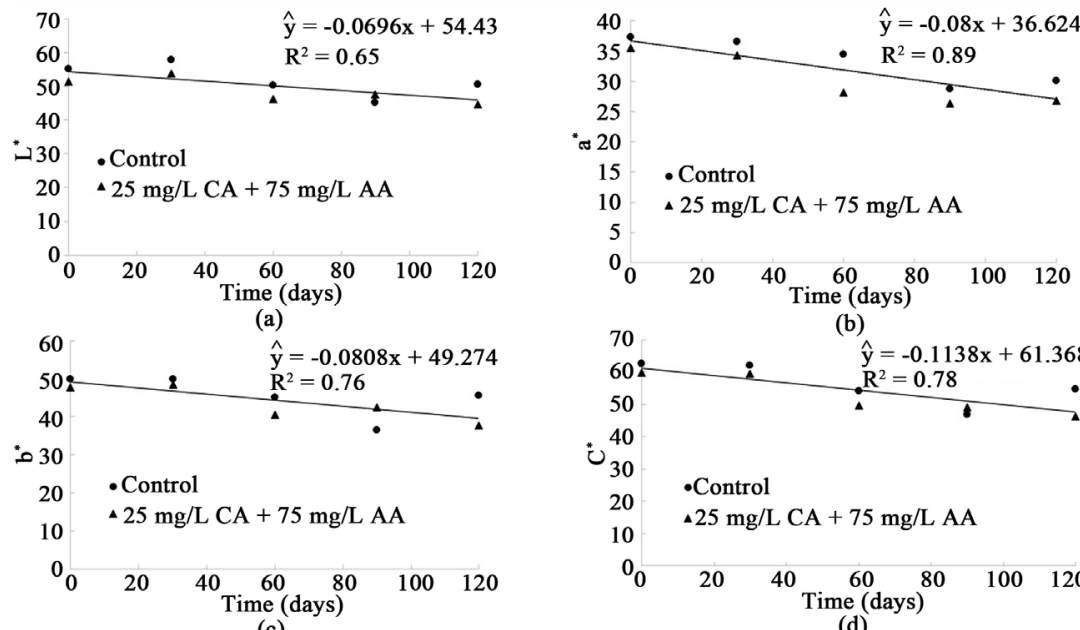

(b)

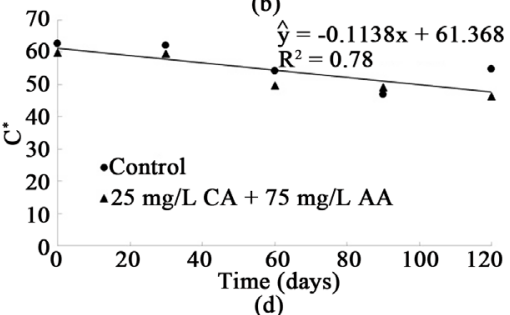

(d)

Figure 2. Color changes of the dried papaya during storage. Lines represent the linear model adjusted. CA: citric acid; AA: ascorbic acid. 


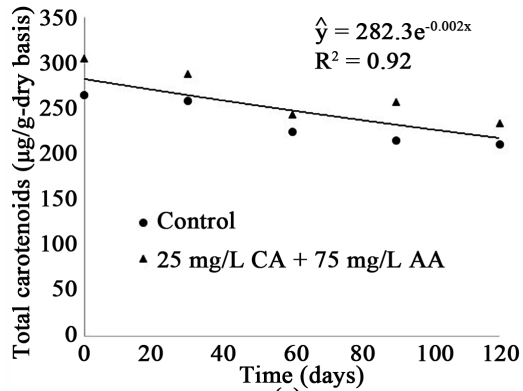

(a)

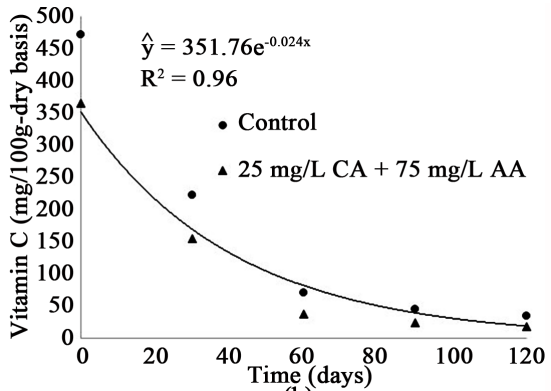

(b)

Figure 3. Degradation of total carotenoids (a) and vitamin C (b) as a function of storage time. Lines represent the exponencial model adjusted. CA: citric acid; AA: ascorbic acid.

Dried papaya moisture remained constant during storage, with a mean value of $23.20 \%$, but water activity increased to 0.64 (Figure $1(\mathrm{~d})$ ). This may have occurred because, in products with low water activity, between 0.20 and 0.60 , small amounts of absorbed water may reflect the increase in water activity, a fact that is represented by the sorption isotherm of dehydrated foods [30].

\subsubsection{Color Changes during Storage}

The dried papaya darkened during storage, probably due to the Maillard reaction, a fact that can be observed by the reduction in $\mathrm{L}^{*}$ values (Figure $2(\mathrm{a})$ ). One of the products of this reaction is hydroxymethylfurfural, which polymerizes with compounds containing amine groups, under less acidic conditions $(\mathrm{pH}>$ 5.0), giving rise to brown pigments called melanoidines. The increase in water activity also favors this reaction, which reaches the maximum between 0.6 and 0.7 [31]. Udomkun et al. [6] also observed the browning of the dried papaya after nine months of storage. Another factor that may have contributed to the browning of papaya is the dehydroascorbic acid oxidation which hydrolyzes to form 2,3-diacetogulonic acid. This substance undergoes polymerization with amino acids such as lysine, glutamic acid and others, promoting the dark pigment formation [9]. According to Hymavathi and Khader [32], the degradation of $\beta$-carotene can also results in the generation of compounds from the Maillard reaction, leading to the browning of the product.

The coordinates $\mathrm{a}^{*}$ and $\mathrm{b}^{*}$ and the $\mathrm{C}^{*}$ attribute also reduced significantly $(p<$ $0.05)$ and the papaya presented a less intense reddish coloration (Figures 2(b)-(d)) after 120 days. On the other hand, the value of $\mathrm{h}^{*}$ remained constant during storage (data not shown). The reduction of these coordinates occurred due to the carotenoids degradation, since the papaya color is the result of $\beta$-carotene, $\alpha$-carotene, cryptoxanthin and lycopene presence.

\subsubsection{Degradation of the Total Carotenoids and Vitamin C during Storage}

Degradation of the total carotenoids during storage followed the first-order reaction (Figure $3(\mathrm{a})$ ). After 30 days, there was a reduction of approximately $6 \%$ of total carotenoid content and after 120 days this reduction was $21 \%$. Probably 
the beginning of the oxidative process occurred during the drying process and with the formation of free radicals the reaction was triggered even in the absence of light. According to Reis et al. [12], besides the oxidative process, the heating that occurs during the dehydration process can promote the redistribution of the cellular food constituents, with the release of acids. These conditions favor the isomerization of the carotenoids from the transform to the cis and these isomers may also undergo oxidation. In addition to color loss, the isomerization and oxidation process results in loss of the pro-vitamin A activity of some carotenoids, such as $\beta$-carotene [33]. The carotenoid content reduced from $282.3 \mu \mathrm{g} / \mathrm{g}$ to $222.06 \mu \mathrm{g} / \mathrm{g}$ and the half-life was 346 days, which indicates that the degradation of these pigments occurred very slowly. Therefore, the use of TEP packaging was efficient in preserving these pigments during storage.

Vitamin $\mathrm{C}$ is often used as a quality index during food processing and storage [24]. It is seen in Figure 3(b) that degradation of this vitamin during storage following the first-order reaction. The vitamin $\mathrm{C}$ content of the dried product reduced from $351.76 \mathrm{mg}$ to $19.75 \mathrm{mg}$ vitamin $\mathrm{C} / 100 \mathrm{~g}$ at 120 days, which represents a reduction of about $94 \%$. The half-life was 29 days, that is, after this period the vitamin $\mathrm{C}$ content was halved. Therefore, dried papaya should be consumed within 30 days of storage to be considered a good nutritional quality product. This result corroborates the values reported by Udomkum et al. [6] in which the half-life time was approximately 30 days in osmotically dehydrated papaya followed by convective drying at $70^{\circ} \mathrm{C}$. In a study carried by Canizares and Mauro [23], the vitamin $\mathrm{C}$ contents retention in dehydrated papayas at temperatures of $60^{\circ} \mathrm{C}$ and $70^{\circ} \mathrm{C}$, was $30.28 \%$ and $48.34 \%$ respectively, after 30 days of storage, values close to the present study.

\subsection{Sensory Acceptance of Dried Papaya}

There was no significant difference $(p>0.05)$ between the two treatments (T1 and T2) regarding sensorial acceptance (Table 3). Sensory acceptance was

Table 3. Sensory acceptance and attribute intensity of dried papaya.

\begin{tabular}{|c|c|c|c|c|c|c|}
\hline \multirow{2}{*}{ Attributes } & \multicolumn{3}{|c|}{ Acceptance Test ${ }^{(1)}$} & \multicolumn{3}{|c|}{ Attribute Intensity ${ }^{(2)}$} \\
\hline & $\mathrm{T} 1^{(3)}$ & $\mathrm{T} 2^{(4)}$ & Average $^{(5)}$ & $\mathrm{T} 1^{(3)}$ & $\mathrm{T} 2^{(4)}$ & Average $^{(5)}$ \\
\hline Color & $5.82 \pm 1.79 a$ & $5.34 \pm 2.03 a$ & $5.58 \pm 0.34$ & $6.18 \pm 1.77 a$ & $6.66 \pm 1.98 \mathrm{a}$ & $6.42 \pm 0.34$ \\
\hline Aroma & $6.12 \pm 1.61 \mathrm{a}$ & $5.44 \pm 1.51 \mathrm{a}$ & $5.78 \pm 0.48$ & $5.04 \pm 2.05 a$ & $5.48 \pm 2.18 \mathrm{a}$ & $5.26 \pm 0.31$ \\
\hline Flavor & $5.42 \pm 1.95 a$ & $5.94 \pm 1.88 \mathrm{a}$ & $5.68 \pm 0.37$ & $5.30 \pm 1.90 a$ & $5.42 \pm 1.99 a$ & $5.36 \pm 0.08$ \\
\hline Texture & $4.90 \pm 2.17 a$ & $5.34 \pm 2.22 \mathrm{a}$ & $5.12 \pm 0.31$ & $6.82 \pm 1.73 a$ & $6.20 \pm 1.67 a$ & $6.51 \pm 0.44$ \\
\hline Overall & $5.70 \pm 1.78 \mathrm{a}$ & $5.36 \pm 1.84 \mathrm{a}$ & $5.53 \pm 0.24$ & - & - & - \\
\hline
\end{tabular}

Means followed by the same letter in the same row are not significantly different $(p>0.05)$ by $\mathrm{F}$ test. (1) mean hedonic score $(\mathrm{n}=50)$ according nine-point scale, with the terms "dislike extremely" (1) and "like extremely" (9). ${ }^{(2)}$ Attribute intensity according to nine-point scale: very light color (1) to very dark (9); weak aroma (1) to strong aroma (9); weak flavor (1) to strong flavor (9); very soft texture (1) very hard texture (9). ${ }^{(3)}$ Control Treatment; ${ }^{(4)}$ Immersion in aqueous solution containing $25 \mathrm{mg} / \mathrm{L}$ citric acid $+75 \mathrm{mg} / \mathrm{L}$ of ascorbic acid for 10 minutes. ${ }^{(5)}$ Average of treatments $\mathrm{T} 1$ and $\mathrm{T} 2$. 
intermediate and the dried papaya was classified as "neither like nor dislike" and "liked slightly". A similar result was obtained Canizares and Mauro [23] for papayas coated with pectin and dehydrated at $60^{\circ} \mathrm{C}$, which received a mean score of 5.30, and papayas coated with pectin added vitamin $C$ that received a mean score of 5.36, for the overall acceptance attribute.

Regarding intensity scale, dried papaya was considered dark (6.42), a fact confirmed by the values of $\mathrm{C}^{*}, \mathrm{~h}^{*}, \mathrm{a}^{*}$ and $\Delta \mathrm{E}$ (Table 1 ). The aroma and taste were considered intermediate (neither strong nor weak), probably due to the loss of part of the volatile compounds during the drying process. The note for the texture was 6.51, indicating that the dried papaya presented a hard texture. Such results may explain the intermediate acceptability of dried papaya.

\section{Conclusions}

The degradation of total carotenoids and vitamin $\mathrm{C}$ followed the first order reaction, and the half-life time was 346 days for carotenoids and 29 days for vitamin C.

After 120 days of storage, the dried papaya darkened and presented less intense reddish coloration. The vitamin C content reduced $94 \%$ and the total carotenoids content reduced $21 \%$.

Sensory acceptance was intermediate and the dried papaya was classified as "neither like nor dislike" and "liked slightly". The aroma and taste were considered intermediate (neither strong nor weak) and the dried papaya presented a hard texture.

Dried papaya must be consumed within 30 days of storage to be considered a good nutritional quality product.

\section{Acknowledgements}

To the Brazilian Agricultural Research Corporation (Embrapa), the National Council for Scientific and Technological Development (CNPq), and the Foundation for Research Support of the State of Bahia (Fapesb), for financial support.

\section{References}

[1] TACO (2011) Tabela brasileira de composição de alimentos. 4th Edition, NEPA-Unicamp, Campinas.

[2] Wall, M.M. (2006) Ascorbic Acid, Vitamin A, and Mineral Composition of Banana (Musa sp.) and Papaya (Carica papaya) Cultivars Grown in Hawaii. Journal of Food Composition and Analysis, 19, 434-445. https://doi.org/10.1016/j.jfca.2006.01.002

[3] Lako, J., Trenerry, V.C., Wahlqvist, M., Wattanapenpaiboon, N., Sotheeswaran, S. and Premier, R. (2007) Phytochemical Flavonols, Carotenoids and the Antioxidant Properties of a Wide Selection of Fijian Fruit, Vegetables and Other Readily Available Foods. Food Chemistry, 101, 1727-1741. https://doi.org/10.1016/j.foodchem.2006.01.031

[4] Zielinski, A.A., Ávila, S., Ito, V., Nogueira, A., Wosiacki, G. and Haminiuk, C.W. (2014) The Association between Chromaticity, Phenolics, Carotenoids, and in Vitro Antioxidant Activity of Frozen Fruit Pulp in Brazil: An Application of Chemome- 
trics. Journal of Food Science, 79, C510-C516.

https://doi.org/10.1111/1750-3841.12389

[5] Mishra, B.B., Gautamn, S., Chander, R. and Sharma, A. (2015) Characterization of Nutritional, Organoleptic and Functional Properties of Intermediate Moisture Shelf Stable Ready-to-Eat Carica papaya Cubes. Food Bioscience, 10, 69-79. https://doi.org/10.1016/j.fbio.2015.02.001

[6] Udomkun, P., Nagle, M., Rgyropoulos, D., Mahayothee, B., Latif, S. and Müller, J. (2016) Compositional and Functional Dynamics of Dried Papaya as Affected by Storage Time and Packaging Material. Food Chemistry, 196, 712-719. https://doi.org/10.1016/j.foodchem.2015.09.103

[7] Fellows, P.J. (2006) Tecnologia do processamento de alimentos: princípios e prática. 2nd Edition, Porto Alegre, Artmed.

[8] Megías-Pérez, R., Gamboa-Santos, J, Soria, A.C., Villamiel, M. and Montilla, A. (2014) Survey of Quality Indicators in Commercial Dehydrated Fruits. Food Chemistry, 150, 41-48. https://doi.org/10.1016/j.foodchem.2013.10.141

[9] Chong, C.H., Law, C.L., Figiel, A., Wojdylo, A. and Oziemblowski, M. (2013) Colour, Phenolic Content and Antioxidant Capacity of Some Fruits Dehydrated by a Combination of Different Methods. Food Chemistry, 141, 3889-3896. https://doi.org/10.1016/j.foodchem.2013.06.042

[10] Sagar V.R. and Kumar, S.P. (2010) Recent Advances in Drying and Dehydration of Fruits and Vegetable: A Review. Journal of Food Science and Technology, 47, 15-26. https://doi.org/10.1007/s13197-010-0010-8

[11] Santos, P.H.S. and Silva, M.A. (2008) Retention of Vitamin C in Drying Processes of Fruits and Vegetables-A Review. Drying Technology, 26, 1421-1437. https://doi.org/10.1080/07373930802458911

[12] Reis, R.C., Ramos, A.M., Regazzi, A.J., Minim, V.P.R. and Stringueta, P.C. (2006) Almacenamiento de mango secado: análisis fisicoquímico, microbiológico, color y sensorial. Ciencia y Tecnología Alimentaria, 5, 214-225. https://doi.org/10.1080/11358120609487694

[13] Maskan, M. (2001) Kinetics of Colour Change of Kiwifruits during Hot Air and Microwave Drying. Journal of Food Engeneering, 48, 169-175. https://doi.org/10.1016/S0260-8774(00)00154-0

[14] Instituto Adolfo Lutz (2008) Métodos físico-químicos para análise de alimentos. 4th Edition, Brasília, Ministério da Saúde.

[15] Rodriguez-Amaya, D. and Kimura, M., Eds. (2004) Harvest Plus Handbook for Carotenoid Analysis. IFPRI and CIAT, Washington DC and Cali.

[16] Oliveira, L.A. (2010) Manual de laboratório: Análises físico-químicas de frutas e mandioca. Embrapa Mandioca e Fruticultura, Cruz das Almas.

[17] Larrauri, J.A., Rupérez, P. and Saura-Calixto, F. (1997) Effect of Drying Temperature on the Stability of Polyphenols and Antioxidant Activity of Red Grape Pomace Peels. Journal Agriculture and Food Chemistry, 45, 1390-1393. https://doi.org/10.1021/jf960282f

[18] Singleton, V.L., Orthofer, R. and Lamuela-Raventós, R.M. (1999) Analysis of Total Phenols and Other Oxidation Substrates and Antioxidants by Means of Folin-Ciocalteu Reagent. Methods in Enzymology, 299, 152-178. https://doi.org/10.1016/S0076-6879(99)99017-1

[19] Rufino, M.S.M., Alves, R.E., Brito, E.S, Pérez-Jiménez, J., Saura-Calixto, F. and Mancini-Filho, J. (2010) Bioactive Compounds and Antioxidant Capacities of 18 
Non-Traditional Tropical Fruits from Brazil. Food Chemistry, 121, 996-1002. https://doi.org/10.1016/j.foodchem.2010.01.037

[20] Re, R., Pellegrini, N., Proteggente, A., Pannala, A.M. and Rice-Evans, C. (1999) Antioxidant Activity Applying Improved ABTS Radical Cation Decolorization Assay. Free Radical Biology and Medicine, 26, 1231-1237. https://doi.org/10.1016/S0891-5849(98)00315-3

[21] Meilgaard, M., Civille, G.V. and Carr, B.T. (2006) Sensory Evaluation Techniques. 4th Edition, CRC Press, Boca Raton.

[22] Rodriguez-Amaya, D.B. (2010) Quantitative Analysis, in Vitro Assessment of Bioavailability and Antioxidant Activity of Food Carotenoids-A Review. Journal of Food Composition and Analysis, 23, 726-740. https://doi.org/10.1016/j.jfca.2010.03.008

[23] Canizares, D. and Mauro, M.A. (2015) Enhancement of Quality and Stability of Dried Papaya by Pectin-Based Coatings as Air-Drying Pretreatment. Food Bioprocess Technology, 8, 1187-1197. https://doi.org/10.1007/s11947-015-1483-2

[24] Garcia, C.C., Caetano, L.C., Silva, K.S. and Mauro, M.A. (2014) Influence of Edible Coating on the Drying and Quality of Papaya (Carica papaya). Food Bioprocess Technology, 7, 2828-2839. https://doi.org/10.1007/s11947-014-1350-6

[25] Hawlader, M.N.A., Perera, C.O., Tian, M. and Yeo, K.L. (2006) Drying of Guava and Papaya: Impact of Different Drying Methods. Drying Technology, 24, 77-87. https://doi.org/10.1080/07373930500538725

[26] Kurozawa, L.E., Terng, I., Hubinger, M.D. and Park, K.J. (2014) Ascorbic Acid Degradation of Papaya during Drying: Effect of Process Conditions and Glass Transition Phenomenon. Journal of Food Engineering, 123, 157-164. https://doi.org/10.1016/j.jfoodeng.2013.08.039

[27] Udomkun, P., Argyropoulos, D., Nagle, M., Mahayothee, B. and Müller, J. (2015) Sorption Behaviour of Papayas as Affected by Compositional and Structural Alterations from Osmotic Pretreatment and Drying. Journal of Food Engineering, 157, 14-23. https://doi.org/10.1016/j.jfoodeng.2015.01.022

[28] Goula, A.M., Adamopoulos, K.G., Chatzitakis, P.C. and Nikas, V.A. (2006) Prediction of Lycopene Degradation during a Drying Process of Tomato Pulp. Journal of Food Engineering, 74, 37-46. https://doi.org/10.1016/j.jfoodeng.2005.02.023

[29] Di Scala, K. and Crapiste, G. (2008) Drying Kinetics and Quality Changes during Drying of Red Pepper. LWT Food Science and Technology, 41, 789-795. https://doi.org/10.1016/j.lwt.2007.06.007

[30] Mujumdar, A.S. (1997) Drying Fundamentals. In: Baker, C.G.J., Ed., Industrial Drying of Foods, Black Academic and Professional, London, 7-30. https://doi.org/10.1007/978-1-4613-1123-2_2

[31] Damodaran, S., Parkin, K.L. and Fennema, O.R. (2010) Química de Alimentos de Fennema. 4th Edition, Artmed, Porto Alegre.

[32] Hymavathi, T.V. and Khader, V. (2005) Carotene, Ascorbic Acid and Sugar Content of Vacuum Dehydrated Ripe Mango Powders Stored in Flexible Packaging Material. Journal of Food Composition and Analysis, 18, 181-192. https://doi.org/10.1016/j.jfca.2004.03.028

[33] Rodriguez-Amaya, D.B. (1999) Changes in Carotenoids during Processing and Storage of Foods. Archivos Latinamericanos de Nutricion, 49, 38S-47S. 